\begin{tabular}{|l|l|}
\hline $\begin{array}{l}\text { 2. To: (Receiving Organization) } \\
\text { Distribution }\end{array}$ & $\begin{array}{l}\text { 3. From: (Originating Organization) } \\
\text { Characterization Engineering }\end{array}$ \\
\hline $\begin{array}{l}\text { 5. Proj./Prog./Dept./Div:: } \\
\text { Characterization Project }\end{array}$ & $\begin{array}{l}\text { 6. Design Authority/Design Agent/Cog. Engr:: } \\
\text { Alois J. Kostelnik }\end{array}$ \\
\hline
\end{tabular}

8. Originator Remarks:

The attached report is submitted for approval and release.

\author{
11A. Design Baseline Document? $\bigcirc$ Yes $\bigcirc$ No
}

\begin{tabular}{l} 
4. Related EOT No.: \\
N/A \\
7. Purchase Order No.: \\
N/A \\
9. Equip./Component No.: \\
N/A \\
10. System/Bldg./Facility: \\
200 General \\
12. Major Assm. Dwg. No.: \\
N/A \\
\hline 13. PermitPermit Applcation No.
\end{tabular}

13. Permit/Permit Application No:

14. Required Response Date:

KEY

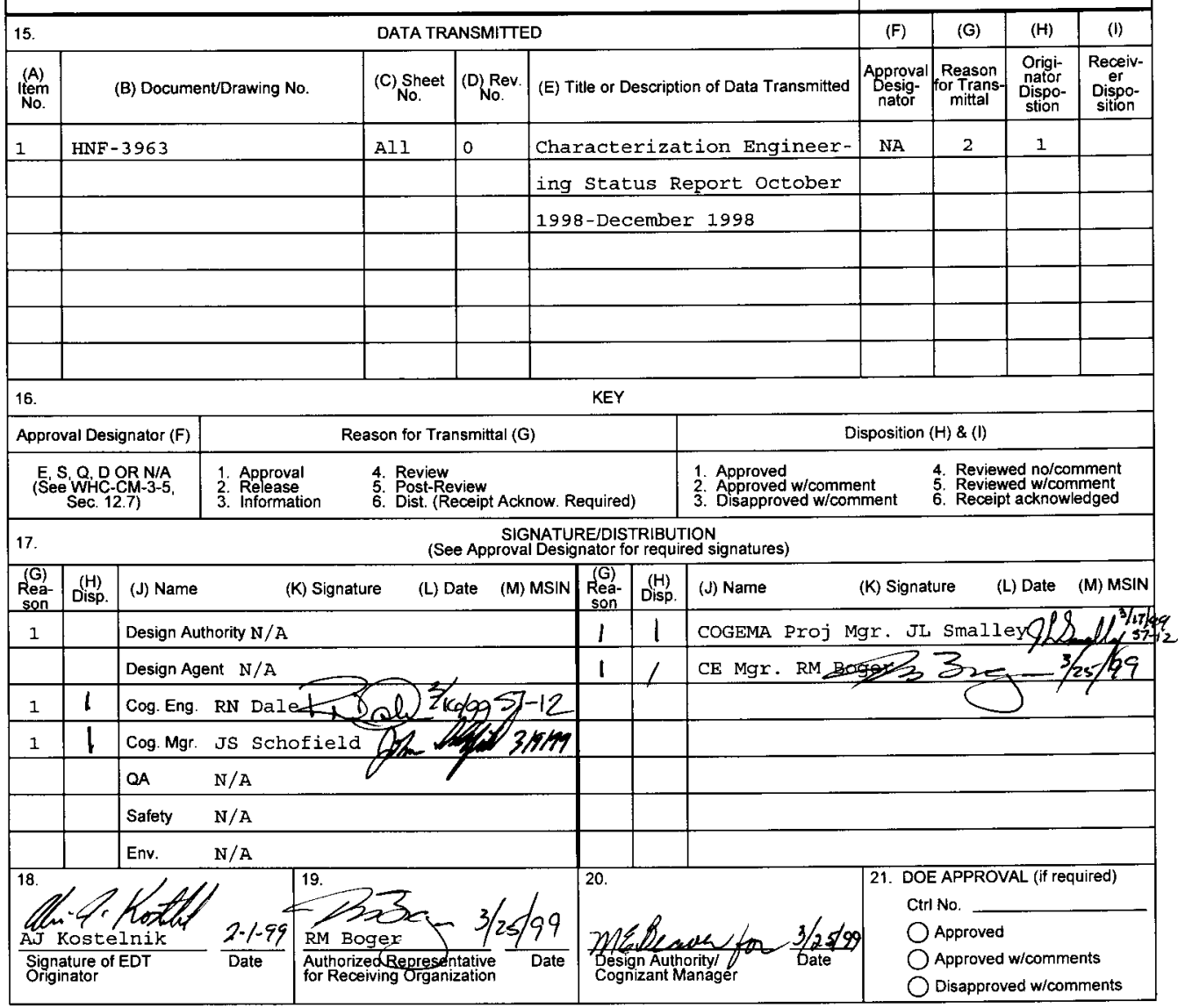




\title{
CHARACTERIZATION ENGINEERING STATUS REPORT OCTOBER 1998 - DECEMBER 1998
}

\author{
R. M. Boger \\ Prepared for Lockheed Martin Hanford Corporation \\ Richland, WA 99352 \\ U.S. Department of Energy Contract DE-AC06-96RL13200
EDT/ECN: $623351 \quad$ UC: 2070
Org Code: $74900 \quad$ Charge Code: $102245 \mathrm{EI} 00$
B\&R Code: 39Ew31301 Total Pages: 34

Key Words: Core Sample Recovery, availability, LDUA, Nested Fixed Depth Sampler, Exhauster, Grab Sample, Vapor Sample, Drill Bits

Abstract: This report contains summary and status for the activities performed by the Characterization Engineering organization during the first quarter of fiscal year 1999.

SAFESEND is a registered trademark of the $3 \mathrm{M}$ Corporation.

TRADEMARK DISCLAIMER. Reference herein to any specific commercial product, process, or service by trade name, trademark, manufacturer, or othenwise, does not necessarily constitute or imply its endorsement, recommendation, or favoring by the United States Government or any agency thereof or its contractors or subcontractors.

Printed in the United States of America. To obtain copies of this document, contact: Document Control Services, P.O. Box 950, Mailstop H6-08, Richland WA 99352, Phone (509) 372-2420; Fax (509) 376-4989.
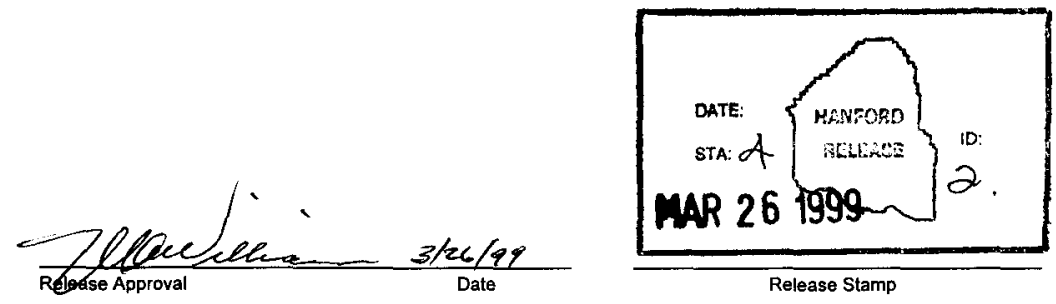

\section{Approved For Public Release}




\title{
CHARACTERIZATION ENGINEERING
}

\section{STATUS REPORT}

\section{OCTOBER 1998 - DECEMBER 1998}

\author{
Prepared By \\ A.J. Kostelnik \\ COGEMA Engineering Corporation \\ Richland, Washington \\ for \\ Characterization Engineering \\ Tank Waste Remediation System \\ Lockheed Martin Hanford Corporation \\ Richland, Washington
}

January 1999 
EXECUTIVE SUMMARY

Table of Contents

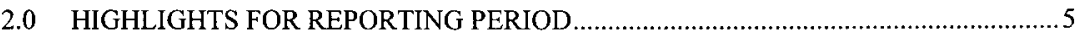

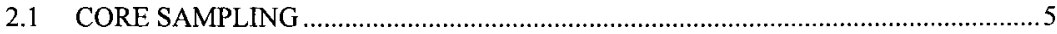

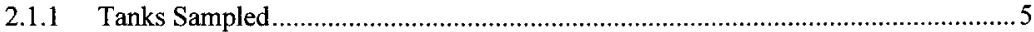

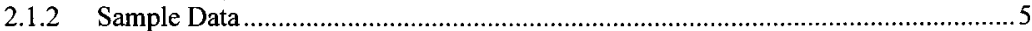

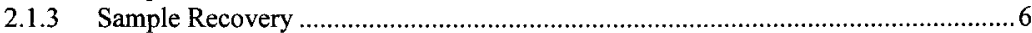

2.1.4 Push-Mode Core Sample Truck \#1 Recovery Analysis .............................................6

2.1.5 Rotary Mode Core Sample Trucks \#3, and \#4 Recovery Analysis ............................

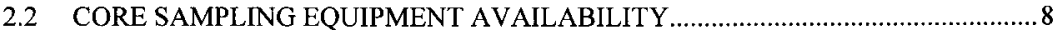

2.3 CORE SAMPLE TRUCK MODIFICATIONS..........................................................

2.4 OTHER CORE SAMPLING EQUIPMENT MODIFICATION …..............................

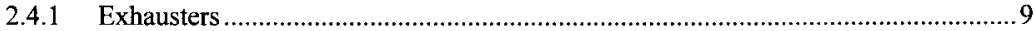

2.4.2 Electrical Generator and Distribution Equipment.................................................. 10

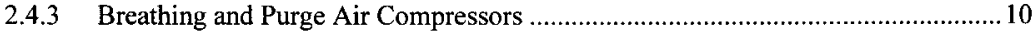

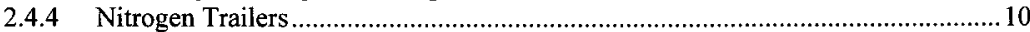

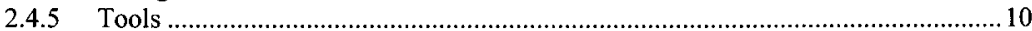

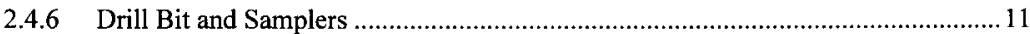

2.5 CHARACTERIZATION PROJECT CONFIGURATION CONTROL ……...................11

2.6 CHARACTERIZATION PROJECT RISER PREPARATION ACTIVITIES ............... 13

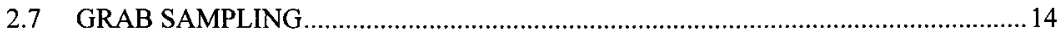

2.8 STANDARD HYDROGEN MONITORING SYSTEM SAMPLING …........................ 14

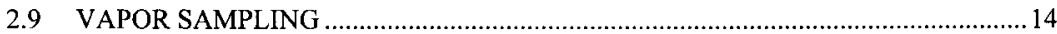

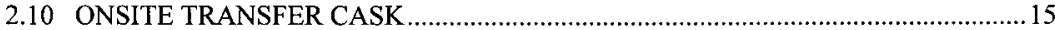

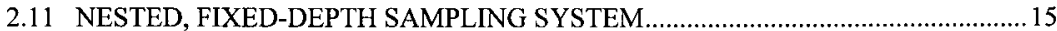

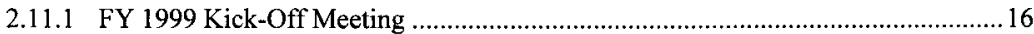

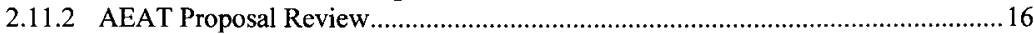

2.11.3 Hanford Technology Management Support.......................................................... 16

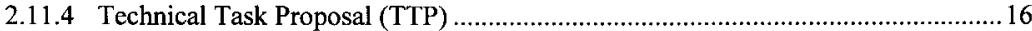

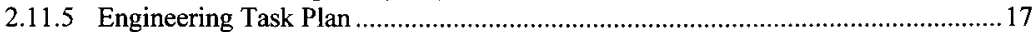

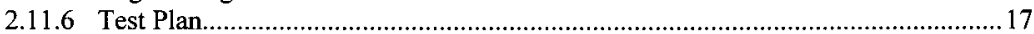

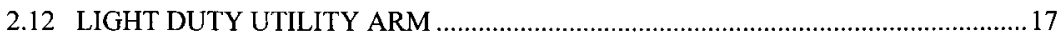

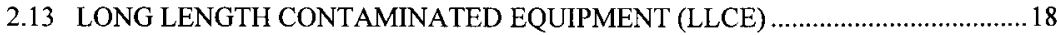

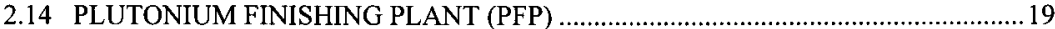

2.15 AUTHORIZATION BASIS AND PERMIT ISSUES …….......................................... 19

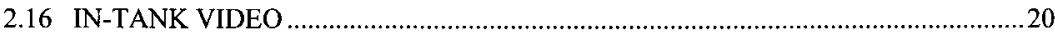

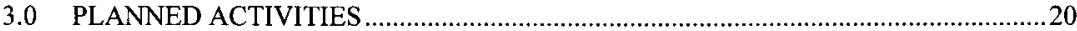

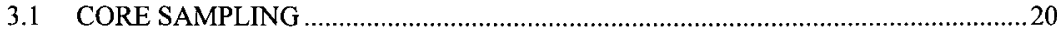

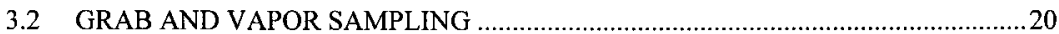

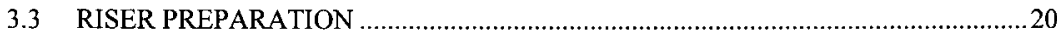

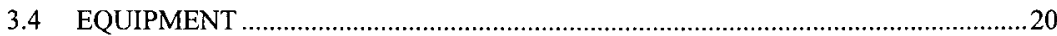

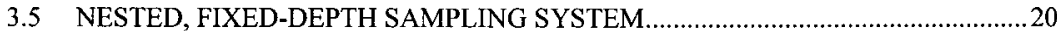

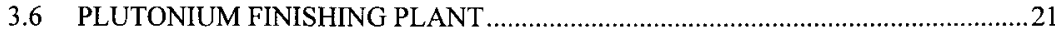

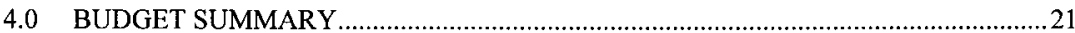

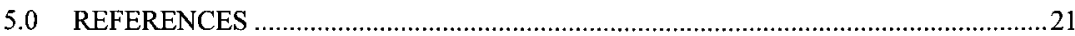




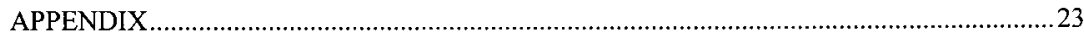

\section{List of Tables}

Table 1: Tank Core Summary for October - December 1998 ……….........................................5

Table 2: Core Sampling Configuration Status .......................................................................12

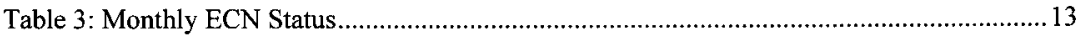

\section{List of Figures}

Figure 1: Preliminary Core Profile for Tank 241-SY-101 .......................................................24

Figure 2: Preliminary Core Profile for Tank 241-TX-113 …………...................................25

Figure 3: Truck \#1: 100 Sample Recovery Performance for October-December 1998 ..............26

Figure 4: Truck \#1: 100 Sample Recovery Performance by Waste Type for October-December 1998

Figure 5: Truck \#2, \#3, \& \#4: 200 Sample Recovery Performance for October-December 1998

Figure 6: Truck \#2, \#3, \& \#4: 200 Sample Recovery Performance by Waste Type for OctoberDecember 1998

Figure 7: Truck \#1 Sampling System Availability ...................................................................30

Figure 8: Truck \#3 Sampling System Availability ………........................................................31

Figure 9: Truck \#4 Sampling System Availability ................................................................... 32

Figure 10:Characterization Equipment Engineering ECN Work Complete Status......................33 


\section{EXECUTIVE SUMMARY}

Characterization Engineering (CE) continues to make progress in support of the project goal of characterizing the Hanford high-level waste tanks. Two core sampling systems were operational during this reporting period-push mode core sampling system \#I and rotary mode core sampling system \#4.

The availability average for core sampling systems \#1, \#3 and \#4, combined, was 45 percent, down from 79 percent for the previous quarter and 58 percent for FY 1998 . System \#2 did not have scope during the quarter, and availability was not tracked. System \#3 was out of service the entire quarter for corrective maintenance.

Two tanks were core sampled during the reporting period, and 24 samples were retrieved. Core sample recovery increased slightly during the quarter. System \#1 average sample recovery increased from 80 percent to 81 percent. The rotary mode core sampling average recovery increased to 62 percent from 55 percent for the previous quarter.

Significant progress was made in other areas as well. Grab Sampling completed sampling six tanks, one more than scheduled. Vapor Sampling was utilized in support of the sluicing of tank 241-C-106 and for emissions monitoring of three exhaust stacks. Increased support was provided for Vapor Sampling the Standard Hydrogen Monitoring Systems. The sampling was necessary due to freezing problems with the field-installed systems.

Preparations are continuing for the Light-Duty Utility Arm (LDUA) deployment with configuration and minor hardware upgrades. The LDUA Operational Readiness Review continues.

The oversight of the Nested, Fixed-Depth Sampler system development has started to increase in order to ensure that a usable system is received when the project is completed.

To improve configuration control, 92 drawing sheet revisions were completed along with the generation of nine new drawing sheets. The number of outstanding Engineering Change Notices increased slightly because of the addition of more drawings into the project.

The stewardship of the Long Length Contaminated Equipment Removal equipment continues to develop. Organizational responsibilities are being identified and documented as well as the scope and deliverables.

The engineering and work planning for opening tank 241-Z-36I at the Plutonium Finishing Plant was completed, and the final reviews to authorize starting work have begun. 


\subsection{INTRODUCTION}

The purpose of this report is to provide the status of activities and plans for Characterization Engineering (CE) activities. The report is meant to provide the status of deliverables to the Characterization Project and other programs and projects supported by $\mathrm{CE}$ for the period from October 1, 1998, through December 31, 1998.

\subsection{HIGHLIGHTS FOR REPORTING PERIOD}

\subsection{CORE SAMPLING}

\subsubsection{Tanks Sampled}

During this reporting period, one push-mode core sampling truck and one rotary-mode core sampling truck were used to obtain core samples from two Hanford waste tanks. Table 1 shows that 24 core segments were obtained from two tank risers. Truck \#1 push-mode core system (PMCS) was used to obtain 22 core segments from tank 241-SY-101, riser 022 (old riser 23A). Truck \#4 rotary-mode core system (RMCS) was used to obtain two core segments from tank 241-TX-113, riser 3. Sampling of these two tanks occurred late in the quarter, and a complete core has not yet been obtained from tank 241-TX-113. Therefore, the information in this report is preliminary and will be updated as more complete data for the two core sampling events become available.

Table 1: Tank Core Summary for October - December 1998.

\begin{tabular}{|c|c|c|c|c|}
\hline Truele & & Tank & Try Core & egments \\
\hline Mluntor & $4 y$ & Muser & Firdinode & Rotaryode \\
\hline 1 & 241-SY-101 & $022(23 \mathrm{~A})$ & 22 & N/A \\
\hline 4 & 241-TX-113 & 3 & N/A & 2 \\
\hline
\end{tabular}

\subsubsection{Sample Data}

Color profiles of the extruded samples continue to be collected and are on file in Characterization Engineering (CE), as well as in the 222-S laboratory. The graphic files of the tank profiles are located on server \\AP012\ACTLOG in the directory COREPROF. 


\subsubsection{Sample Recovery}

Figures 1 and 2 show the core profiles for each tank listed in Table 1. The core samples for tank 241-SY-101 were all obtained using push mode. Core samples from tank 241-TX-113 were obtained using both push and rotary modes. A number of parameters, including suspected waste hardness, moisture content, and past core history, were used to select the coring mode. Rotary-mode core sampling was used to repeat a core segment when a high down force was experienced in push mode.

Figure 1 shows a preliminary core profile for the segments recovered from tank 241-SY-101 using truck \#1; not all the data required to generate a complete profile or final recoveries were available at the time this report was prepared. For eight of the 22 segments of core 255 , the recovery rate ranged from $0 \%$ to $95 \%$ with an average recovery rate of approximately $82 \%$. These recoveries were obtained from moist and wet saltcake. (These recoveries were computed assuming a full stroke of $48 \mathrm{~cm}$ [19 inches]; final recoveries will be determined from available X-ray data and actual stroke lengths.)

Figure 2 shows a preliminary core profile for the two segments recovered from tank 241-TX-113 using truck \#4; not all the data required to generate a complete profile or final recoveries were available at the time this report was prepared. For the two segments recovered to date for core 253 , the recovery rate ranged from approximately $2 \%$ to $5 \%$. These recoveries were obtained from dry saltcake. (These recoveries were computed assuming a full stroke of $48 \mathrm{~cm}$ [19-inches]; final recoveries will be determined from available X-ray data and actual stroke lengths.)

\subsubsection{Push-Mode Core Sample Truck \#1 Recovery Analysis}

NOTE: The recovery data tracked in this and the subsequent rotary-mode section were reviewed for consistency with letter of instruction, Schofield 1996. Some recovery data were found to be inconsistent with the LOI and were dropped from the statistical analysis. Therefore, the data presented in this report may appear different from past presentations of these data, and data reported in this quarterly report are not compared with data from past reports.

Figure 3 shows the core recovery performance for Truck \#1 during this reporting period. Figure 3 includes the preliminary recovery data for eight of the 22 core segments from tank 241-TX-101; the data may change when final recovery data become available. Figure 3 shows the individual segment recoveries for the last 100 core segments, the running average of the last 100 core segments, and the $80 \%$ recovery goal. The last point on the average recovery curve shows that the current average recovery has stayed steady at a value of $81 \%$. Recovery data for the last 100 core segments show that

- Overall, $73 \%$ of the segments had recoveries greater than or equal to $80 \%$.

- Of the segments with recoveries greater than or equal to $80 \%$, approximately $7 \%$ are first segments and $10 \%$ are last segments.

- Of the segments with recoveries less than $80 \%$, approximately $22 \%$ are first segments and $19 \%$ are last segments. 
- Of the segments with recoveries greater than or equal to $80 \%$, approximately $19 \%$ are retained gas samples (RGS); of the segments with recoveries less than $80 \%$, approximately $30 \%$ are RGS samples.

Figure 4 shows the average recovery for the last 100 samples grouped according to the major material recovered as identified by the 222-S laboratory. The figure indicates that for the last 100 core segments

- Liquid, wet saltcake, and moist saltcake waste materials have average recoveries greater than or equal to $80 \%$.

- In order of decreasing recovery, salt slurry, "other" (combination or unidentified waste types), wet sludge, and dry saltcake waste materials have average recoveries less than $80 \%$.

- Waste types identified as sludge slurry or dry sludge did not appear in the last 100 segments, and thus no recovery statistics were computed for these waste types.

- Sample recovery is poorest for dry saltcake, with a recovery of $37 \%$.

\subsubsection{Rotary Mode Core Sample Trucks \#3, and \#4 Recovery Analysis}

Figure 5 shows the current recovery performances for Trucks \#2,\#3, and \#4. The figure shows the individual segment recoveries for the last 200 core segments, the running average of the last 200 core segments, and the $60 \%$ recovery goal. As indicated in Table 1, one of three RMCS trucks (Truck \#4) was used to obtain tank cores during this reporting quarter. The average recovery of the last 200 segments is $62 \%$. Recovery data for the last 200 segments show that

- Overall, $58 \%$ of the samples have recoveries greater than or equal to $60 \%$.

- Of the segments with recoveries greater than or equal to $60 \%$, approximately $9 \%$ are first segments and $14 \%$ are last segments.

- Of the segments with recoveries less than $60 \%$, approximately $15 \%$ are first segments and $12 \%$ are last segments.

Figure 6 shows the average recovery for the last 200 samples grouped according to the major material category identified during segment extrusion at the 222-S Laboratory. The number of segments for each material category is also shown. For the last 200 Core segments

- Waste types with recoveries greater than or equal to $60 \%$ are (in order of decreasing recovery): liquid, wet saltcake, sludge slurry, and "other" (combination or unidentified waste types). 
- Waste types with recoveries less than $60 \%$ are (in order of decreasing recovery): wet sludge, moist saltcake, dry sludge, salt slurry, and dry saltcake.

- Similar to Truck \#1, dry saltcake recovery continues to be low.

- The most prevalent waste types recovered are mixtures/unidentified ("other") followed by liquids and dry saltcake.

\subsection{CORE SAMPLING EQUIPMENT AVAILABILITY}

As reported previously, the working definitions for availability and reliability of sampling equipment have been established (Janicek 1995). As defined, the availability of core sampling systems is tracked daily.

The average equipment availability, (based on a 52-week moving average) for the reporting period increased from $62 \%$ to $63 \%$ for RMCS system \#3, and decreased to $51 \%$ from $54 \%$ for RMCS system \#4. The data is shown graphically in Figures 7, 8 and 9.

CST \#1 was deployed on tank 241-SY-101 during the period. The system was available $69 \%$ during the period. The availability was not tracked for the previous period because there was no defined scope for use of CST \#1.

RMCST \#3 System was out of service for the entire period because of a Bellows Assembly failure on the truck. A new Bellows Assembly was not available in spares, and the manufacturing facility in Florida burned down. During the period an extensive amount of work was done with a new manufacturer to reproduce the design. The new bellows was received at the end of the reporting period. During the fourth quarter of FY 1998, the system was available $90 \%$ of the time.

RMCST \#4 system availability for the period was $44 \%$. The system was out of service for 64 shifts due to required calibration on the purge gas flow pressure transducer and tank farm RADCON issues surrounding the performance of the calibration in the field. During the fourth quarter of FY 1998, the system was available $68 \%$ of the time.

All CST systems, \#1, \#3, and \#4, combined for $45 \%$ availability for the quarter, down from $79 \%$ for the previous quarter.

\subsection{CORE SAMPLE TRUCK MODIFICATIONS}

Modifications to CST \#1 performed this quarter include modification of the grapple hoist chain drive guard to improve safety and facilitate chain tension adjustment, improvements to the grapple hoist slack cable detection system, and installation of a window in the grapple box cover to facilitate troubleshooting. There are no modifications pending for Authorization Basis (AB) compliance for CST \#1. Design improvements remaining include 1) addition of kick plates on the platform and improved gates for the railing, 2) shielded receiver hole cover installation, 3) air compressor upgrade, 4) traverse hydraulic check valve installation, and other minor modifications.

The bellows was removed from CST \#2 for use on RMCST \#3. Close inspection after removal showed the bellows assembly might not be capable of operating at the high pressures required for RMCS and was not reinstalled. The CST \#2 quill rod and grapple box have been temporarily sealed without the bellows in place. 
An Engineering Task Plan (ETP) and Engineering Change Notice (ECN) were written, and released, that will remove some unused equipment from CST \#2 for use as spare parts to support rotary mode core sampling operations with RMCST \#3 and \#4. The manufacturer of the purge gas flow monitoring instrumentation on the core sample trucks no longer produces a critical component (the alarm/display module) of the system. This flow monitoring system is used only for rotary mode core sampling, not during push mode core sampling. The purge gas flow monitoring systems for the core sample trucks have three loops for monitoring flow. Each loop is independent of the other two and each loop can generate its own alarms. A minimum of two loops is needed for rotary mode core sampling. The RMCSTs can still operate with one inoperative purge gas-monitoring loop. The limited on-site spares, coupled with the manufacturer's production termination of the alarm/display module, create a potential problem. The three alarm/display modules on CST \# 2 will be removed and modified for use on the RMCSTs. After modification and testing, the modules will be placed in the spare parts inventory.

RMCST \#3 was not modified during the period. There are no modifications pending for AB compliance. Design improvements remaining to be performed include installation of an air filter upstream of the purge gas flow control valves, shielded receiver hole cover installation, replacement of the alarm horn and bell, and installation of banana jacks on the down force system.

RMCST \#4 was not modified during the period. There are no modifications pending for AB compliance. Design improvements remaining to be performed include installation of an air filter upstream of the purge gas flow control valves, shielded receiver hole cover installation, replacement of the alarm horn and bell, and installation of banana jacks on the down force system.

A draft alternative study was prepared during the period and is out for review. The study includes ten options for CST \#1 and CST \#2 for upgrades or removal from service.

\subsection{OTHER CORE SAMPLING EQUIPMENT MODIFICATION}

\section{4,1 Exhausters}

During a maintenance activity it was discovered that the fuses for the Variable Frequency Drive (VFD) on the RMCS Exhausters were of the incorrect rating. Two (2) ECNs were written to replace the fuses on both Exhausters. The replacement of the VFD power supply fuses for Exhauster B was completed last quarter, and Exhauster $\mathrm{C}$ was completed this quarter. The manufacturer's specification sheet for the new fuses has been added to the Vendor Information file via an Engineering Data Transmittal.

An Engineering Task Plan (ETP) has been drafted that outlines the installation of Continuous Air Monitor (CAM) high radiation shutdown interlocks on the RMCS exhausters. The ETP was written in anticipation of the Department of Energy's (DOE) approval of Addendum 5 to the Basis for Interim Operation (BIO). The addendum will require an automatic shutdown on the Exhausters when a high radiation level is detected in the exhaust stack. The draft ETP has been reviewed, and numerous comments have been received. The ETP will be revised with the pertinent comments and redistributed for signatures and release. 


\subsubsection{Electrical Generator and Distribution Equipment}

Modifications to correct all National Electrical Code (NEC) discrepancies are nearly complete. Modifications to the last generator are in progress at the end of the quarter. (The modifications were completed during the preparation of this report.)

\subsubsection{Breathing and Purge Air Compressors}

No Modifications were performed, and there are no changes pending.

\subsubsection{Nitrogen Trailers}

The second of the three nitrogen trailers (NT-C) was upgraded to the ambient vaporizer system during the period. The remaining trailer (NT-A) will be modified during the next reporting period.

Sound level testing was performed on the nitrogen dewar vent system in response to an employee safety concern. The evaluation by the Industrial Safety representative concluded that, for the frequency and duration of the operation of venting the nitrogen dewar for transportation, supplemental hearing protection would be adequate. The Industrial Safety representative specified electronic muffs to be used for hearing protection in the immediate vicinity of the valve during venting.

\subsubsection{Tools}

Several pieces of field equipment in Characterization Project Operations (CPO) were tested for Year 2000 (Y2K) compliance a few months ago. A TWRS internal audit is being performed on the $\mathrm{Y} 2 \mathrm{~K}$ documentation. During the internal audit some minor issues were raised about the test documentation for some CPO equipment. During a meeting with Mel Adams, Point of Contact (POC) for TWRS Y2K efforts, the issues were addressed to his satisfaction. Mr. Adams will write a response to address the internal audit findings and any resolutions. A document detailing the Characterization field equipment $\mathrm{Y} 2 \mathrm{~K}$ compliance will be drafted at a later date. During $\mathrm{Y} 2 \mathrm{~K}$ testing of equipment, it was discovered that two laptop computers were not $\mathrm{Y} 2 \mathrm{~K}$ compliant. The computers are used for data acquisition and calibration activities in the field. Two replacement computers were ordered and received. The new laptops have had the necessary software transferred to them and tested for operation and $\mathrm{Y} 2 \mathrm{~K}$ compliance. 
Stress analysis of the Down Force Calibration Stand was completed. This analysis determined that the stand is adequate to support the $5700-\mathrm{lb}$. maximum down force by a core sample truck. The stand will be used to calibrate the down force monitoring and control systems on the CSTs. The stand provides increasing resistance to the drill string as deflection increases. The original design used heavy steel springs, which were not securely confined. The new design replaced the steel springs with a single-bladder type air spring. The compression of the bladder is guided by heavy steel rods which also limit extension should the stand move during use. During the period, fabrication of the improved Down Force Calibration Stand was completed, and all redline changes made during fabrication have been included in the configuration documentation.

Stress analysis of the Sampler Retrieval Tool was completed. This analysis was required to prove that the Sampler Retrieval Tool will not fail structurally when subjected to a 1000-lb. load. Failure within a tank riser could lead to sparking and, possibly, flammable gas ignition.

The maintenance platform used to support the technicians performing maintenance on the CSTs was modified to include kick plates.

\subsubsection{Drill Bit and Samplers}

ECNs and procedure changes were prepared to support deployment of the Knife-edge sampler system. Sampler fabrication was started, and drill bits were ordered during the period. The Knife-edge samplers and drill bits will be deployed when a smooth transition can be made with respect to the authorization basis, sampler inventory, and sampling schedule.

\subsection{CHARACTERIZATION PROJECT CONFIGURATION CONTROL}

During the reporting period additional drawings were incorporated into the Characterization Project for Configuration Control. The system drawings added include Vapor Sampling equipment, Grab Sampling equipment, and Auger Sampling equipment.

The breakdown of the drawings is shown in Table 2 below with the current status of all core sampling and Light-Duty Utility Arm (LDUA) drawings. 
HNF-3963

Rev 0

Table 2: Core Sampling Configuration Status

\begin{tabular}{|c|c|c|c|c|c|c|}
\hline Equipment & $\begin{array}{c}\text { Sheets } \\
\text { with } \\
\geq 10 \mathrm{ECNs}\end{array}$ & $\begin{array}{c}\text { Sheets } \\
\text { with } \\
\geq 5 \mathrm{ECNs}\end{array}$ & $\begin{array}{c}\text { Sheets } \\
\text { with } \\
<5 \text { ECNs }\end{array}$ & $\begin{array}{c}\text { Total } \\
\text { Sheets } \\
\text { with ECNs }\end{array}$ & $\begin{array}{l}\text { Sheets } \\
\text { with } \\
\text { 0 ECNs }\end{array}$ & $\begin{array}{c}\text { Total } \\
\text { Drawing } \\
\text { Sheets }\end{array}$ \\
\hline Trucks $3 \& 4$ & 0 & 1 & 68 & 69 & 209 & 278 \\
\hline Truck 2 & 2 & 3 & 113 & 118 & 91 & 209 \\
\hline Truck 1 & 0 & 1 & 53 & 54 & 46 & 100 \\
\hline Trucks $1 \& 2$ & 3 & 6 & 24 & 33 & 22 & 55 \\
\hline Support / Ancillary & 1 & 10 & 95 & 106 & 138 & 244 \\
\hline Exhausters & 0 & 2 & 16 & 18 & 100 & 118 \\
\hline Other Equipment & 0 & 3 & 18 & 21 & 9 & 30 \\
\hline LDUA $^{*}$ & 0 & 0 & 89 & 89 & 139 & 228 \\
\hline TOTALS & 6 & 26 & 476 & 508 & 754 & 1262 \\
\hline
\end{tabular}

* LDUA drawings include only the H-6 series drawings that are released in the Hanford Document Control System and do not include the PNNL and SPAR Aerospace Limited drawings contained in the Vendor Information files.

The Characterization Engineering goal is to maintain the number of work completed ECNs at greater than $75 \%$ of the total number of outstanding ECNs. In addition, a generally declining trend is expected in the total number of outstanding ECNs. No specific numerical goal is set since the number of ECNs is affected by the nature and number of modifications dictated by changing requirements or desired enhancements.

Progress this period towards incorporating ECNs and revising drawings for accurate configuration control includes the following:

- 9 new drawing sheets were released, (8 LDUA, 1 Support),

- 92 drawing sheets were revised with ECNs incorporated, (including 61 Essential drawings),

- 13 drawing sheets were voided,

- 39 ECNs were released,

- 13 ECNs were signed "Work Complete," and

- 73 ECNs were incorporated. 
HNF-3963

Rev 0

Table 3 below represents the monthly status of ECNs. Figure 10 is a graphic representation of the data below.

Table 3: Monthly ECN Status

\begin{tabular}{|r|l|l|l|l|l|l|l|l|l|l|l|l|}
\hline Month & Jan & Feb & Mar & Apr & May & Jun & Jul & Aug & Sep & Oct & Nov & Dec \\
\hline Total ECNs & 600 & 548 & 485 & 502 & 509 & 485 & 489 & 466 & 418 & 404 & 405 & 447 \\
\hline Work Complete ECNs & 300 & 288 & 345 & 378 & 377 & 362 & 366 & 365 & 324 & 302 & 300 & 340 \\
\hline \% of Total ECNs & $50 \%$ & $53 \%$ & $65 \%$ & $75 \%$ & $74 \%$ & $75 \%$ & $75 \%$ & $78 \%$ & $78 \%$ & $75 \%$ & $74 \%$ & $76 \%$ \\
\hline Goal & \multicolumn{10}{|c}{$---75 \%---$} \\
\hline
\end{tabular}

During the previous quarter, an engineering study (Wilson 1998a) was prepared that recommended classifying the core sampling system drawings as Essential, Support, or General. This engineering study recommended classifying 119 drawing sheets as Essential and 333 sheets as Support. During this quarter, the Essential Drawing List (Wilson 1998b) was updated to partially incorporate the recommendations of the engineering study. Of the 1262 drawing sheets in the Characterization Project, 103 sheets are Essential and 211 sheets are Support. The drawing sheets for CST \#1 and CST \#2 were not classified because the additional cost of maintaining the drawings is not justified without a definite future need for the trucks.

There are 14 Essential drawing sheets with outstanding "Work-Complete" ECNs: 6 sheets for the LDUA, which are not funded for revision, and the remaining 8 sheets that are in the revision process.

\subsection{CHARACTERIZATION PROJECT RISER PREPARATION ACTIVITIES}

The evaluation of risers that can be used to support sampling activities was continued. The files that document the riser preparation activity are maintained on the Hanford Local Area Network (HLAN), on file server AP012 in shared area ACTLOG. To access the information assign (map) a drive letter to network folder, \AP012\ACTLOG. The files are located in the RISERS directory.

Support was provided for the permanent removal of the gas-monitoring probe from tank 241-SY-101, riser 021. Access to this riser was required to provide an additional location for a core sample from 241-SY-101. This gas probe is no longer required, and it was permanently removed to facilitate core sampling. The support of this activity involved the preparation of an Unreviewed Safety Question (USQ) Determination and an ECN.

Work continued on tank 241-Z-361. This tank is an inactive, underground storage tank located within the protected area of the Plutonium Finishing Plant (PFP). The scope of the work is to understand and control the potential hazards associated with $241-Z-361$, and includes the following

- Setting up equipment on tank

- Initial opening of tank and breather filter installation

- Vapor sampling of tank head space

- Obtaining video of the tank interior 
Early in the second quarter 1999, the work packages to set up the equipment, open the tank, and install the breather filter were approved by the PFP Plant Review Committee (PRC). The work planning and USQ screenings to support vapor sampling and video continues. The work packages to accomplish the vapor sampling and in-tank video should be ready for the PFP PRC to review by the end of January 1999. By the end of the second quarter, the fieldwork on all of the above items should be complete.

Two temporary ECNs were closed during the first quarter. The ECNs involved the temporary removal of ENRAF level gauges from tanks 241-SX-102 and 241-U-109 to support the core sampling of these tanks.

\subsection{GRAB SAMPLING}

Grab Sampling has currently sampled six (6) tanks. According to the Baseline Sampling Schedule revision 5.5, only five (5) tanks were to be grab sampled for the FY 1999 baseline sampling schedule. Two (2) of the tanks sampled were funded from other projects, while four (4) tanks were funded to support Characterization.

The sampling of AW-102 was delayed for the AP farm transfers to be completed. Sampling of this tank has been delayed three (3) months until mid-February. Milestones associated with the Evaporator Campaign 99-1 are affected.

Grab Sampling has completed sampling for two post-batch sluicing phases, and is being delayed for post-batch \#1.1.3 to take place. The attempted volume of transfer has been less than the amount specified in HNF-2958. According to the schedule, grab sampling is currently behind by two post-batches. It is unknown at this time when the sluicing operations will begin.

\subsection{STANDARD HYDROGEN MONITORING SYSTEM SAMPLING}

TWRS Characterization has continued to set the sample schedule requirements on a month-to-month basis on which Standard Hydrogen Monitoring Systems (SHMS) are to be sampled. All SHMS cabinets called out to date have been sampled for the month assigned. This program started in October 1997.

High moisture content in the SHMS process lines has been plugging the SHMS filter inside the cabinet. The operation of some of the SHMS is limited to a short period of time each day. CPO has had to make special arrangements with Tank Farm Operations to obtain the samples. The number of affected SHMS has been slowly increasing each month.

\subsection{VAPOR SAMPLING}

Tank 241-S-106 was injected with tracer gas to support the safety analysis of saltwell pumping and the Tank Safety Issue Resolution activity FG03446B30.

Ammonia and vapor grab samples were taken from the recently installed 296-C006 ventilation system before sluicing of 241-C-106 commenced to meet Project W-320 requirements. Due to an unexpected vapor release from the ventilation system during sluicing activities, additional vapor samples were required. These vapor samples were taken from the following three locations: 1) 296-C-006 exhaust stack; 2) 241-AY-102 SHMS probe; 3) 702-AZ ventilation system. The resulting data will aid in the design of equipment that will capture fugitive stack emissions and protect workers. 


\subsection{ONSITE TRANSFER CASK}

Work was performed on an alternate onsite transport package system to ship $500-\mathrm{ml}$ waste samples in support of privatization. The SAFESENDß, which currently satisfies the requirements, is in limited supply and does not offer any shielding for the $500-\mathrm{ml}$ samples. Because of dose restrictions, CPO is limited to transporting only one $500-\mathrm{ml}$ sample in a SAFESEND per shipping truck. Replacing the SAFESEND(B) with a shielded non-containment vessel will allow CPO to obtain 500-ml sludge samples from all tanks within the Hanford Site, reducing the whole body dose exposure and allowing for more than one $500-\mathrm{ml}$ sample to be transported on the authorized shipping trucks. The advantages gained include a reduction of operating expense (ability to ship more than one sample per truck) and a reduction in operator dose.

The shielded non-containment vessels (steel pigs) are to be expanded to include shipment of the $125-\mathrm{ml}$ samples. By inserting a sampler carrier into the cavity of the shielded non-containment vessel, more than one $125-\mathrm{ml}$ sample may be shipped in the onsite sample pig transport system. The Safety Analysis Report for Packaging (McCoy 1998) allows for a maximum of $500 \mathrm{ml}$ to be shipped at one time in the sample pig transport system for all tanks within the Hanford Site.

At present CPO is able to ship only one $125-\mathrm{ml}$ sample in the sample pig transport system. The current shielded non-containment vessel cavity limits shipments to only one $125-\mathrm{ml}$ sample. Using the $500-\mathrm{ml}$ steel pig to ship the $125-\mathrm{ml}$ samples will allow for an increase in the number of $125-\mathrm{ml}$ samples that can be shipped and will also decrease the cost.

The Engineering Task Plan has been written and approved. A purchase order has been placed to purchase 20 steel pigs. The SARP update is in the approval process. The SARP will authorize the use of the steel pig with the previously authorized shipping pig package system.

\subsection{NESTED, FIXED-DEPTH SAMPLING SYSTEM}

The TWRS Privatization Contract with British Nuclear Fuels (BNFL) requires that the PHMC provide waste batches that conform to the feed envelopes A, B, and C, as specified in the contract. The BNFL privatization contractor will be responsible for waste separation, treatment, and glassification, but the Hanford Site has the responsibility of supplying waste feed materials in a suitable condition and within a scheduled time interval. To ensure that these waste conditions are met, the contents of the PHMC team staging tank will be sampled and analyzed prior to the transfer to the Privatization Contractor(s)' tanks. The current approved method for sampling tank liquids is "grab" sampling, which uses a "bottle on a string" technique. The issues with this sampling method include a bias with materials from the upper tank elevations, inability to sample while the mixer pump is operating, and the operator exposure required to complete this manual sampling process. An additional concern is that the amount of time required to ensure that a tank is well mixed may preclude grab sampling staged batches of waste feed.

To address these concerns, a representative, rapid sampling and analysis system is being developed with support from EM-50's Tank Focus Area (TFA), Characterization Monitoring and Sensor Technology (CMST), International Grant Programs, and Federal Energy Technology Center (FETC). The first task is to develop a sampling system that can provide waste samples representative of a tank's waste content. A second task is to develop an at-tank analysis system (in-tank or at-tank deployments are options at this time) that provides on-line, 
real-time sample analysis data and can be interfaced with the sampling system. AEA Technology Engineering Services, Inc. (AEAT) is a private firm that is contracted to develop a nested, fixed depth, sampling system. This system is based on fluidic pumping technology that AEAT has previously applied to nuclear and chemical sampling problems. CE is providing technical support and integration within the PHMC team that is supporting the development of the sampler system and the at-tank analysis system. The $\mathrm{CE}$ activities for the last quarter include the following.

\subsubsection{FY 1999 Kick-Off Meeting}

A FY 1999 Kick-Off meeting was held on the Hanford Site with representatives from TFA, International Programs, and Robotics programs. The agenda included status of FY 1998 carry-over tasks and planning for FY 1999 tasks (including activities in the FY 1999 Technical Task Proposal (TTP)). A schedule was established for the carry-over tasks that included revision of the Test Plan, AEA Statement of work, Level 2 Component Specification, and the Engineering Task Plan documents. The review also briefly included activities with the at-tank analysis system that will be developed with a non-government contract through CMST. CMST has funded the Federal Energy Technology Center (FETC) to implement the development of an at-tank analysis system through a private contract.

\subsubsection{AEAT Proposal Review}

Several telephone conference calls were held with AEAT, EM-50 TFA representatives, and members of the PHMC nested, fixed-depth sampling system technical team to review and discuss AEAT's draft proposal for their FY 1999 work scope. The funding for this work scope will be provided from a DOE International Grants program. In FY 1999, AEAT will complete two tasks: Task 1- Proof-of-Principle testing with a conceptual sampling channel and Task 2Completion of an Outline Design for a prototype nested, fixed-depth sampling system. Cost estimates from AEAT required the delay of several conceptual system tests and the Detailed Design activity until FY 2000.

\subsubsection{Hanford Technology Management Support}

A summary of the FY 1998 testing completed by AEAT, with the conceptual nested, fixed-depth sampling system, was prepared for input to a data sheet being prepared by the Technology Management Organization at Fluor Daniel Hanford (FDH). Technology Management, FDH has the responsibility of tracking new technology applications for the Hanford Site.

\subsubsection{Technical Task Proposal (TTP)}

A FY 1999 TTP was developed, for input to EM-50 TFA programs, that includes the AEA FY 1999 activities; Task 1- Proof-of-Principle testing and Task 2- Outline Design completion dates. The TTP defines the work scope, schedule, and funding for the PHMC support in the development of this sampling system and an at-tank analysis system that will use the waste stream from the sampling system. The revised TTP outlines the activities and milestones for FY 1999 and summarizes the projected activities for the project out-years 
(2000 through 2004). The AEA projected costs and schedules for testing and design, as indicated above, have delayed a number of future activities by at least one year. The TTP activities also include technical support for the development of the sampling system and the attank analysis system, Engineering Task Plan, Level 2 Component Specification, and Test Plan activities.

\subsubsection{Engineering Task Plan}

The Engineering Task Plan (Reich 1998a) (ETP) includes scope, schedule, and fund allocations for the PHMC FY 1999 and projected out-year activities for the sampling system and the at-tank analysis system. A Revision 1 ETP was prepared and reviewed by Characterization Engineering. Comments were incorporated and the revision distributed for a second review. In the revision process, several cost estimates were prepared to address potential "funding" issues. The basic concern was that the TTP is initially funded at an $80 \%$ level. In the revision process, several tasks, including a preliminary hazard assessment, were projected to be delayed until FY 2000 for an $80 \%$ scenario. However, full funding has not been authorized by TFA for FY 1999. Additional task modifications were made to reflect the AEA Task 1 Proof-of-Principle testing and Task 2 Outline Design completion dates.

\subsubsection{Test Plan}

The Test Plan (Reich 1998b) outlines proof-of-principle tests that AEA will complete with a conceptual sampling system. This test plan also identifies some of the testing that will be required with the prototype sampling system that is expected to be at Hanford in FY 2001. The Test Plan was revised based on lessons-learned from the FY 1998 AEAT testing, from Savannah River's work with a fixed-depth sampling system, and on AEAT's proposed FY 1999 PTP activities. Revisions to the Test Plan have been prepared and distributed for review and comment.

\subsection{LIGHT DUTY UTILITY ARM}

The Characterization Project is conducting a Management Self-Assessment (MSA) for the readiness to deploy the LDUA in single-shell tank 241-AX-104. The LDUA is planned to retrieve up to 15 samples of the accessible residual waste on the tank bottom, wall ribs, and dome. The mission is the first extensive sampling campaign in tank $241 \mathrm{AX}-104$, and laboratory analysis results are expected to provide information on analyte concentration and spatial variability, validate auger sample results, and ultimately reduce the large uncertainty associated with the radionuclide and hazardous chemical inventory in the tank. The MSA started July 15 to verify the readiness for operation prior to a FDH contractor Operational Readiness Review (ORR) and a Department of Energy, Richland Operations Office (RL) ORR. The LDUA is currently on track for deployment in April 1999.

The open items from the walkdown of the LDUA drawings were resolved and documented in Barnes 1998.

Because of lessons learned from recent ORRs, the LDUA MSA has been very detailed, and procedures and training have been revised. The final training, drill preparation, and PMs have been delayed because of failures of the LDUA equipment and availability of personnel due to higher priority work. This delay in completion of the training has delayed completion of the 


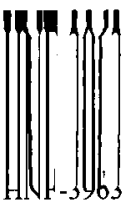

Rev 0

MSA. There is a moderate risk that Performance Agreement (PA) 1.1.1, Performance

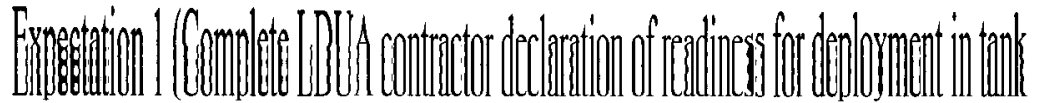

241-AX-104 by March 11, 1999) will not be met. The reasons for this condition are the equipment reliability problems. Actions are being taken to reduce problems by identifying potential changes if or when additional failures occur. This will allow for faster return to service. More permanent solutions are being investigated.

\subsection{LONG LENGTH CONTAMINATED EQUIPMENT (LLCE)}

There are approximately 1,200 long-length equipment items mounted in TWRS SSTs and DSTs, and about 100 of them must be removed to support full tank waste retrieval operations. Typical items to be removed are old saltwell screens, failed thermocouple trees, and unused pumps. Specially engineered removal equipment, collectively called the Long Length Contaminated Equipment (LLCE) Removal System, has been designed, fabricated, and tested in preparation for the retrieval of these designated TWRS long-length equipment items and the packaging for their disposal.

The current task is to maintain the intended capability of the LLCE System, which includes establishing the operational baseline (e.g., operating procedures, maintenance procedures, and associated activities) and the design baseline (e.g., design requirements, configuration control).

The major challenges in FY 1999 will be to

- Provide a plan for physical storage of the LLCE System and associated components and parts,

- Implement those portions of the storage plan that are appropriate for FY 1999,

- Provide the engineering plans and specifications for future storage/maintenance buildings according to the plan/schedule,

- Complete an Acceptance for Beneficial use (ABU) for the LLCE System with a final or partial punchlist, as appropriate,

- Provide a plan to complete the design baseline punchlist items and issue it as a part of an ETP,

- Complete the design baseline punchlist items that are appropriate for FY 1999, and

- Provide revised LLCE Technical Basis Review (TBR) narratives (..120 \& ...122)

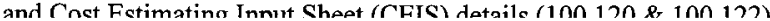


MSA. There is a moderate risk that Performance Agreement (PA) 1.1.1, Performance Expectation 1 (Complete LDUA contractor declaration of readiness for deployment in tank 241-AX-104 by March 11, 1999) will not be met. The reasons for this condition are the equipment reliability problems. Actions are being taken to reduce problems by identifying potential changes if or when additional failures occur. This will allow for faster return to service. More permanent solutions are being investigated.

\subsection{LONG LENGTH CONTAMINATED EQUIPMENT (LLCE)}

There are approximately 1,200 long-length equipment items mounted in TWRS SSTs and DSTs, and about 100 of them must be removed to support full tank waste retrieval operations. Typical items to be removed are old saltwell screens, failed thermocouple trees, and unused pumps. Specially engineered removal equipment, collectively called the Long Length Contaminated Equipment (LLCE) Removal System, has been designed, fabricated, and tested in preparation for the retrieval of these designated TWRS long-length equipment items and the packaging for their disposal.

The current task is to maintain the intended capability of the LLCE System, which includes establishing the operational baseline (e.g., operating procedures, maintenance procedures, and associated activities) and the design baseline (e.g., design requirements, configuration control).

The major challenges in FY 1999 will be to

- Provide a plan for physical storage of the LLCE System and associated components and parts,

- Implement those portions of the storage plan that are appropriate for FY 1999 ,

- Provide the engineering plans and specifications for future storage/maintenance buildings according to the plan/schedule,

- Complete an Acceptance for Beneficial use (ABU) for the LLCE System with a final or partial punchlist, as appropriate,

- Provide a plan to complete the design baseline punchlist items and issue it as a part of an ETP,

- Complete the design baseline punchlist items that are appropriate for FY 1999, and

- $\quad$ Provide revised LLCE Technical Basis Review (TBR) narratives (...120 \& ...122) and Cost Estimating Input Sheet (CEIS) details (100.120 \& 100.122).

To avoid future confusion and clearly identify the more significant implementation issues, drafts for an LLCE Memorandum of Understanding (MOU) and an ETP have been written and circulated for comment. An ABU checklist is an attachment to the draft ETP and will receive approval with the ETP. Reviewer comments are now being collected on second generation drafts, and resolution of all comments should be completed in January. When approved, these two documents will provide the basis for a working interface relationship between Characterization Engineering and all projects that currently plan to use the LLCE 
removal equipment. The MOU will prove to be especially helpful in resolving issues associated with stewardship of the LLCE removal equipment.

Planning for physical storage of the LLCE Removal System is proceeding. A draft engineering study of the storage options will be available for comment in late January. The engineering study will address all LLCE Removal System requirements, and a procurement action for appropriate storage facilities is anticipated in this fiscal year.

A list of the LLCE Removal System design baseline documents has also been provided in the draft ABU checklist. A cognizant engineer will be selected during this fiscal year and will be responsible for developing a punchlist of design baseline document items for resolution.

\subsection{PLUTONIUM FINISHING PLANT (PFP)}

Tank 241-Z-361 is a 20,000-gallon miscellaneous underground storage tank managed by the Babcock and Wilcox Hanford Company. The tank contains some amount of plutonium and may also contain pressurized flammable gases. CE is supporting the approach and design for installing a breather filter, taking a gas sample, and viewing the tank internal features.

During the last quarter, fabrication of two (2) inlet breather filters for tank 241-Z-361 was completed. An ECN was issued to incorporate all redline changes made during fabrication.

A draft specification for a bridge to span tank 241-Z-361 was completed and issued for review. A bridge may not be required, depending on the outcome of the tank structural inspection. However, because of a short timeline, it was deemed prudent to write the specification and be prepared should the bridge be required.

Two work packages were created to perform the initial venting and breather filter installation on tank 241-Z-361. The first package will be used to prepare the work site, set up the containment tent, and perform cleanup after the job is completed. The second package will be used to perform the initial riser opening and install a permanent breather filter. A mockup was assembled to help develop these work procedures and to facilitate training.

An ECN was written against the tank 241-Z-361 drawing to show the breather filter installation on the tank. In addition, a USQ Determination and an USQ Screening were also completed, which verified that the work packages and ECN are within the bounds of the existing tank 241-Z-361 Authorization Basis (Ramble 1999).

The work packages, USQs, and ECNs have been approved by CPO and the PFP Plant Review Committee. This work is planned for mid-February. Immediately following the completion of this work, vapor samples will be taken and tank intrusive video work will be performed to assist in the structural assessment of the tank.

\subsection{AUTHORIZATION BASIS AND PERMIT ISSUES}

Tier II review questions by RL on the incorporation of Leach 1997 into LMHC 1998 have been resolved satisfactorily. Safety and Licensing personnel are now finalizing the formal PHMC response to RL. Schedule information has not been provided by RL for Tier III review. Characterization Field Engineering personnel expended approximately three weeks of effort during the quarter to assist with the resolution of concerns raised by RL on the Authorization Basis for the LDUA. 
Work continued on the documentation of RMCS particulate generation properties. The document will support future Notices of Construction for the RMCS and SX Tank Farm exhausters. Preparation of the revised SX Tank Farm exhauster Notice of Construction was recently suspended due to funding cuts.

CE prepared 34 Unreviewed Safety Question (USQ) Screenings and five (5) Determinations during the period, without any issues raised concerning the quality of the content.

\subsection{IN-TANK VIDEO}

The ETP for the in tank video system was prepared and sent out for review. The ETP outlines the work required to upgrade or replace the current camera system that is used to get video data from the waste tanks. The task includes an Alternatives Generation Analysis prior to pursuing upgrade or replacement.

A separate ETP was prepared and is in the final approval process for the work required to procure a new, high-output, purged light system to supplement the existing light provided on the video camera. This task is being performed as a specification and procurement of an engineered system.

\subsection{PLANNED ACTIVITIES}

\subsection{CORE SAMPLING}

The sampler and bit interface will be changed during the next period to the Knife-edge sampling system. The Knife-edge sampling system was shown to improve the capability to recover non-consolidated solid waste forms.

\subsection{GRAB AND VAPOR SAMPLING}

Radioactive particulate samples will be taken from 241-U-102 to support saltwell Notice of Construction (NOC) permit for the Washington Department of Health (WDOH).

\subsection{RISER PREPARATION}

Continued support will be provided throughout the next reporting period for riser identification and preparation for sampling activities.

\subsection{EQUIPMENT}

The remaining nitrogen purge supply trailer, NT-B, will be upgraded. Procurement of a light to support in tank video will begin.

\subsection{NESTED, FIXED-DEPTH SAMPLING SYSTEM}

Continued support for development of the Nested, Fixed-Depth Sampling system will be provided. CE will revise the planning for FY 1999 activities to include the additional testing and oversight required to demonstrate a useable system for the Hanford site. 


\subsection{PLUTONIUM FINISHING PLANT}

Continued support will be provided for installing a breather filter, taking a gas sample, and viewing the internal features of tank $241-361-\mathrm{Z}$.

\subsection{BUDGET SUMMARY}

Preliminary budget results for the first quarter of FY 1999 indicate that CE actual costs are running under budget projections. Most of this can be accounted for due to level loading budget without allowance for contractor and purchase order invoice delays. Also some task activities are not scheduled to start until later in the fiscal year.

\subsection{REFERENCES}

Janicek G. P., 1995, Sampling Equipment Availability/Reliability Improvement, Engineering Task Plan, WHC-SD-WM-ETP-171, Rev. 0, Westinghouse Hanford Company, Richland, Washington.

Leach, C. E., 1997, A Safety Assessment of Rotary Mode Core Sampling in Flammable Gas Single Shell Tanks: Hanford Site, Richland Washington, HNF-SD-WM-SAD-035, Rev. Ob, Lockheed Martin Hanford Corporation, Richland, Washington.

LMHC, 1998, Tank Waste Remediation System Basis for Interim Operation, HNF-BIO-001, Rev. 1, Lockheed Martin Hanford Corporation, Richland, Washington.

McCoy, J. C., 1998, Safety Analysis Report for Packaging (Onsite), Onsite Transfer Cask, HNF-SD-TP-SARP-002, Rev.1-C, Waste Management Northwest, Richland, Washington.

Schofield, J. S., 1996, Sample Recovery Measurement Parameters (Internal memo 75210-4, June 24, 1996) Westinghouse Hanford Company, Richland, Washington

Wilson, G. W., 1998a, Drawing Evaluation Report for Sampling Equipment Drawings, HNF-2305, Rev.0, Lockheed Martin Hanford Corporation, Richland, Washington.

Wilson, G. W., 1998b, Characterization Equipment Essential Drawing Plan, HNF-3240. Rev.2, Lockheed Martin Hanford Corporation, Richland, Washington.

Reich, F. R., 1998a, Engineering Task Plan for Development, Fabrication, and Deployment of Nested Fixed-Depth Fluidic Sampling and At-Tank Analysis Systems, HNF-2056, Rev. 0, Lockheed Martin Hanford Corporation, Richland Washington

Reich, F. R., 1998b, Test Plan for Evaluating the Operational Performance of the Prototype Nested Fixed-Depth Fluidic Sampler, HNF-3042 Rev.0, Lockheed Martin Hanford Corporation, Richland Washington. 
HNF-3963

Rev 0

Ramble, A. L., 1999, Justification for Continued Operation for Tank 241-Z-361, HNF-2024

Rev.1, Babcock and Wilcox Hanford Corporation, Richland, Washington. 


\section{APPENDIX}

Figure 1: Preliminary Core Profile for Tank 241-SY-101 ....................................................24

Figure 2: Preliminary Core Profile for Tank 241-TX-113 ..................................................25

Figure 3: Truck \#1: 100 Sample Recovery Performance for October-December 1998 ..............26

Figure 4: Truck \#1: 100 Sample Recovery Performance by Waste Type for October-December 1998

Figure 5: Truck \#2, \#3, \& \#4: 200 Sample Recovery Performance for October-December 1998

Figure 6: Truck \#2,\#3, \& \#4: 200 Sample Recovery Performance by Waste Type for OctoberDecember 1998

Figure 7: Truck \#1 Sampling System Availability ……………..............................................30

Figure 8: Truck \#3 Sampling System Availability ………………...........................................31

Figure 9: Truck \#4 Sampling System Availability …….......................................................... 32

Figure 10:Characterization Equipment Engineering ECN Work Complete Status......................33 

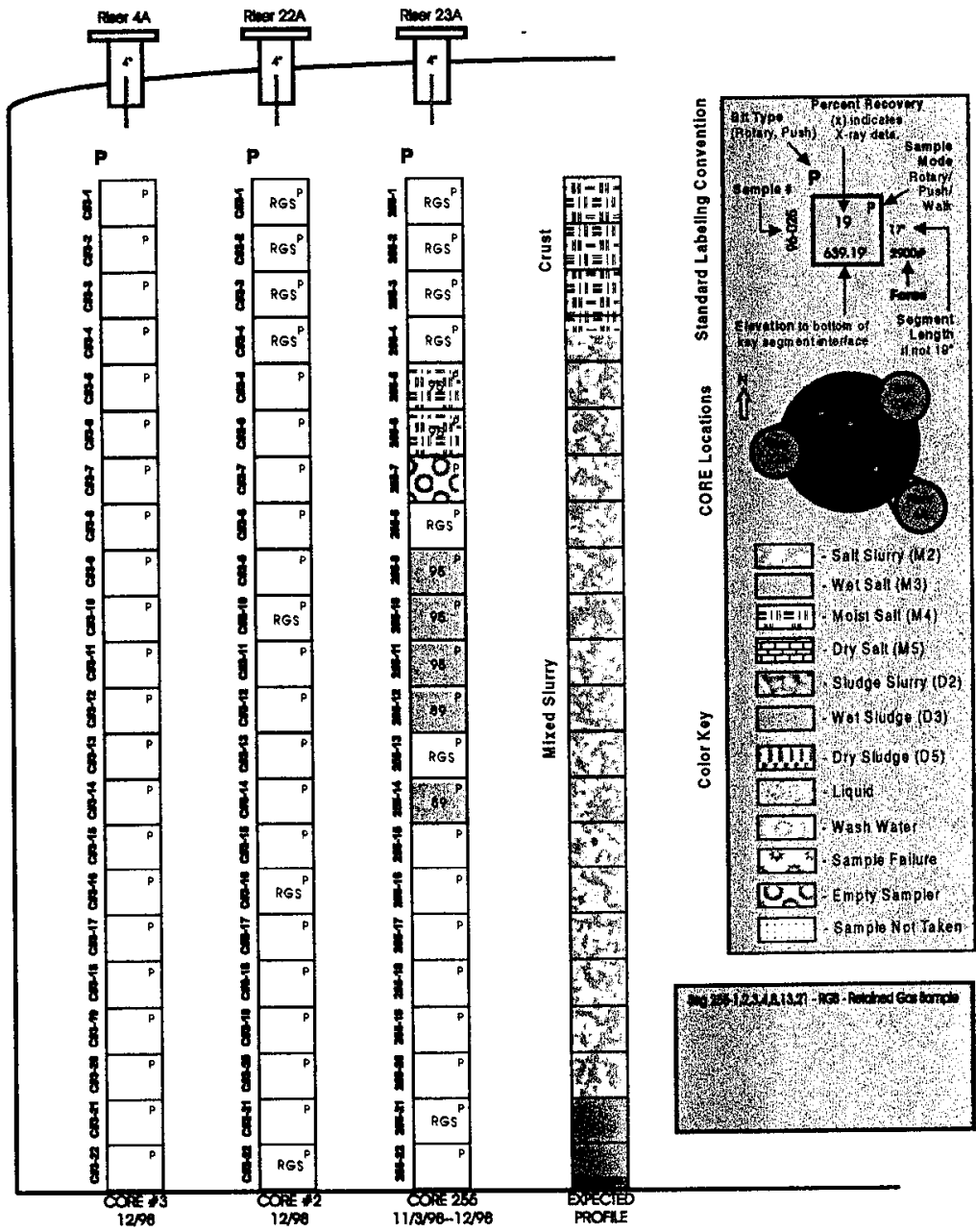
Figure 2: Preliminary Core Profile for Tank 241-TX-113

\section{TX-113 RMCS CORE PROFILE}

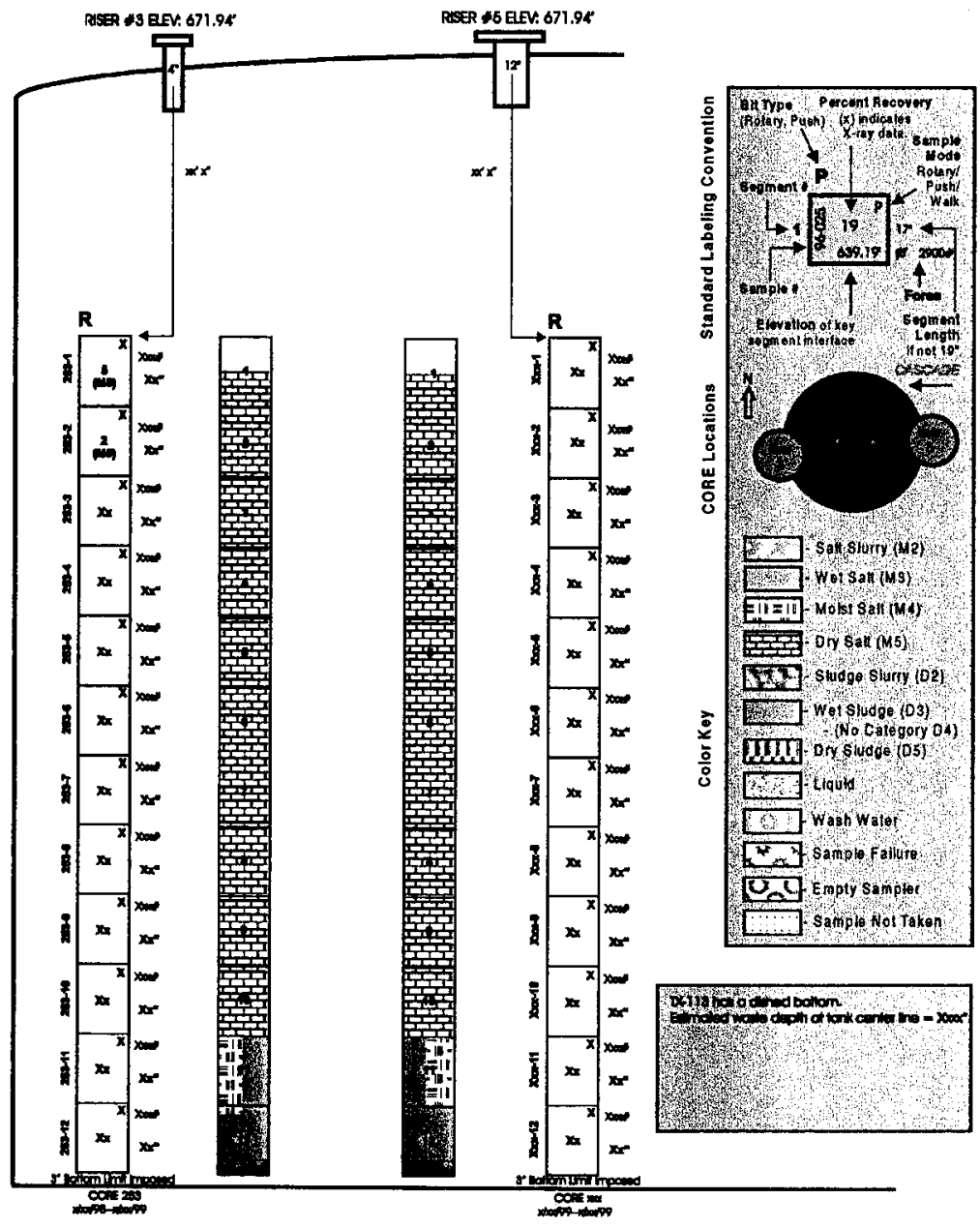

FILE: TX-113(12-98).cdr
DATE: $12 / 28 / 98$

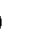


Figure 3: Truck \#1: 100 Sample Recovery Performance for October-December 1998

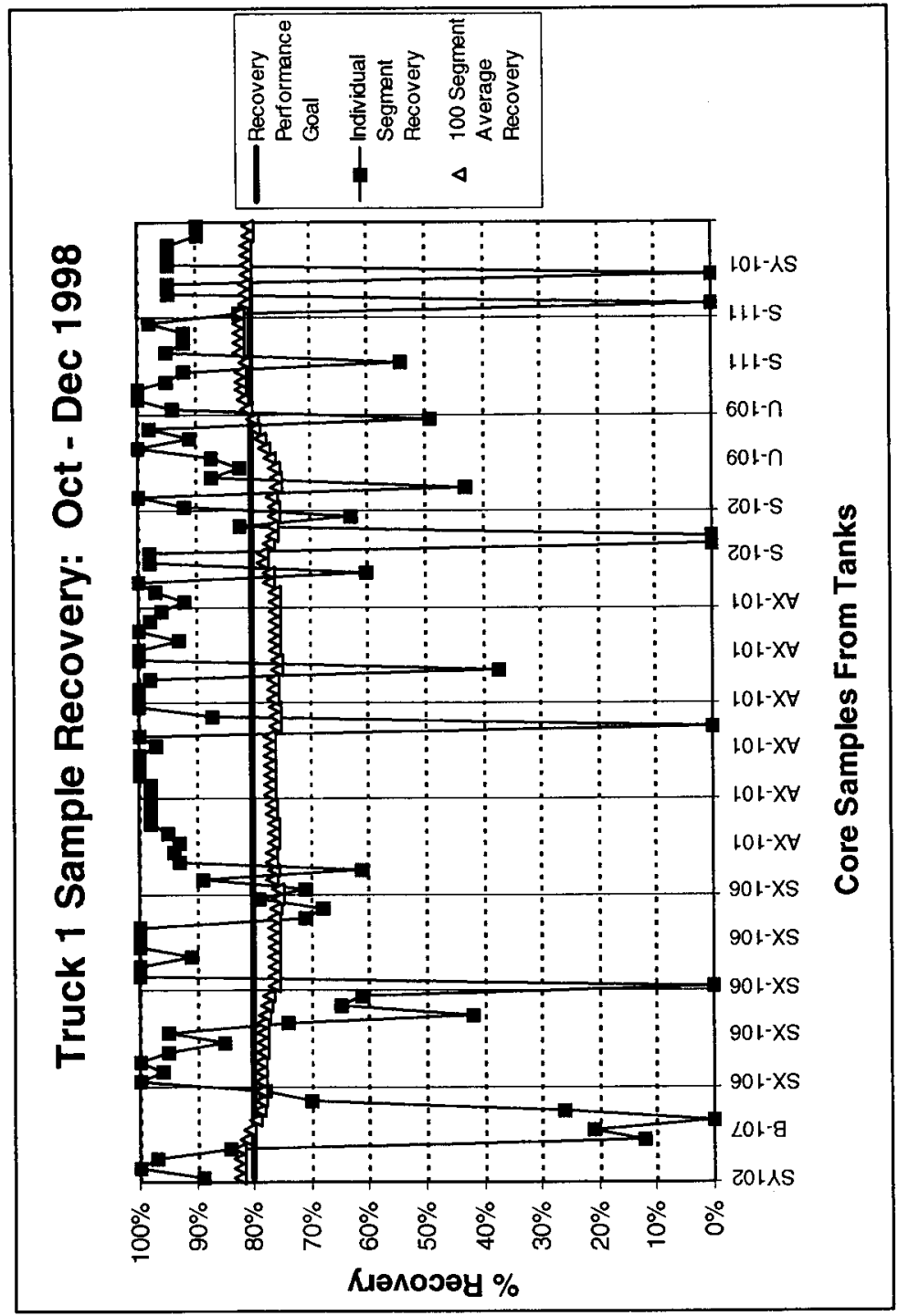


Figure 4: $\quad$ Truck \#1: 100 Sample Recovery Performance by Waste Type for OctoberDecember 1998

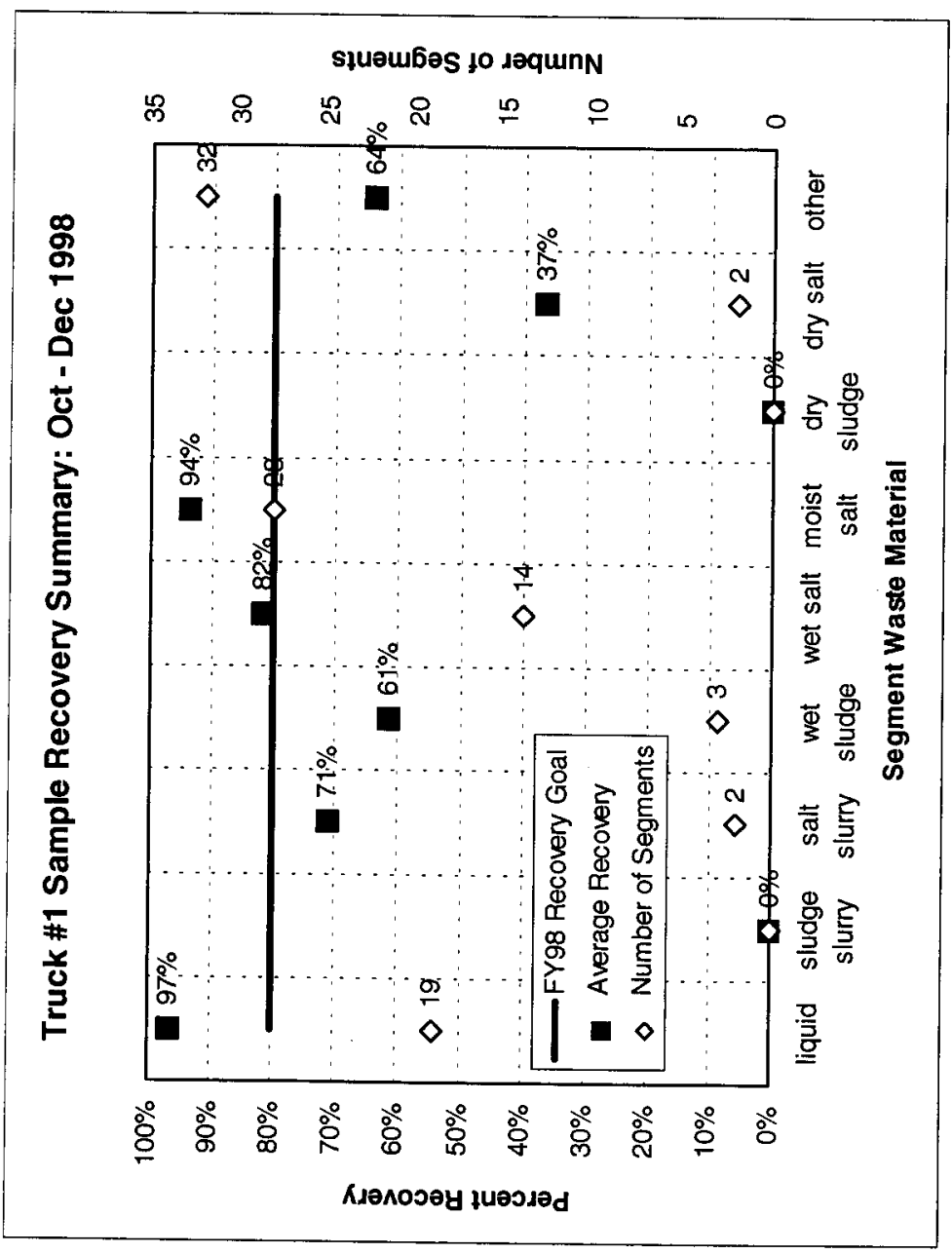


Figure 5: $\quad$ Truck \#2, \#3, \& \#4: 200 Sample Recovery Performance for October-December 1998

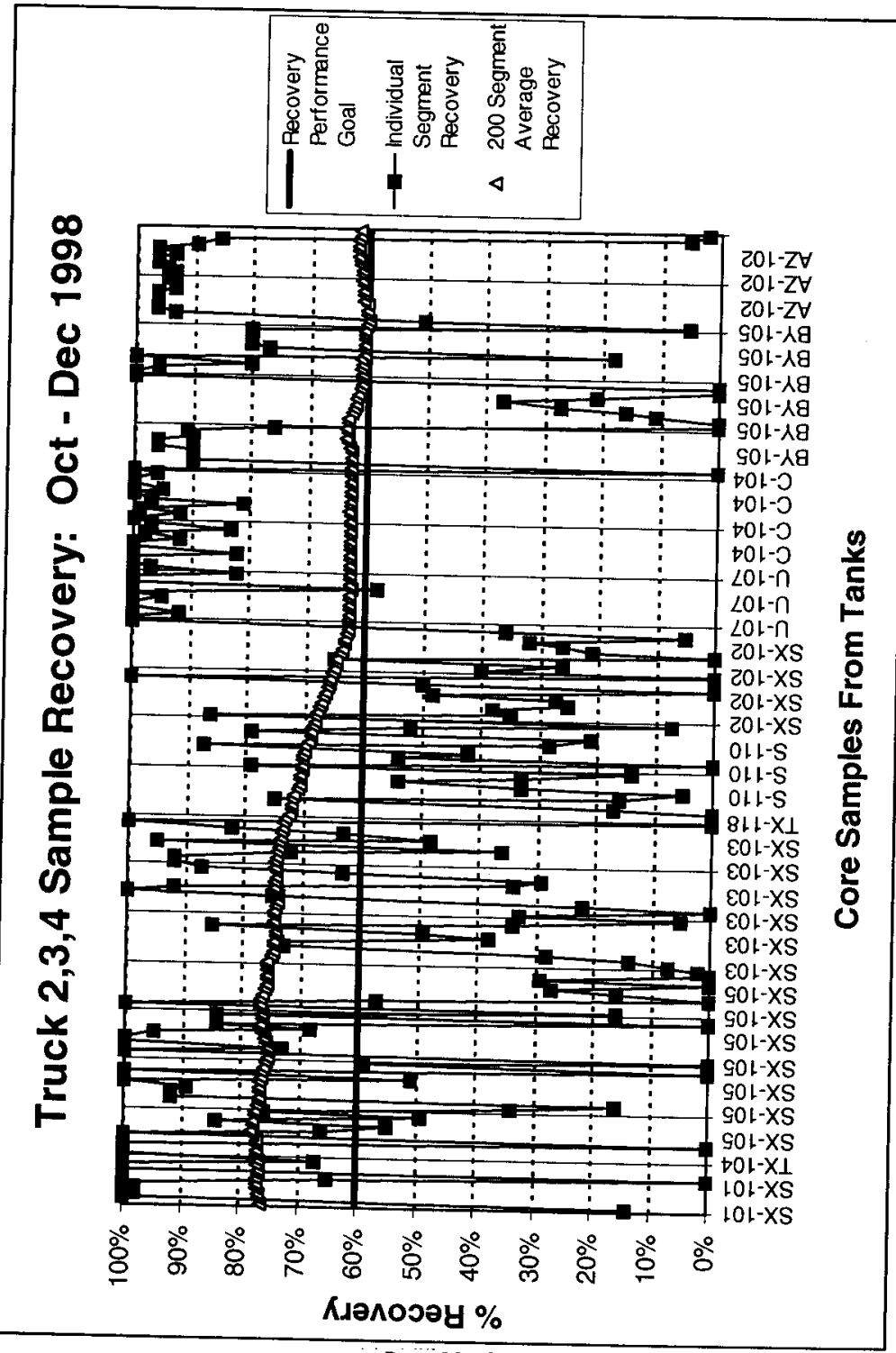

Page 28 of 33 
Figure 6: $\quad$ Truck \#2, \#3, \& \#4: 200 Sample Recovery Performance by Waste Type for October-December 1998

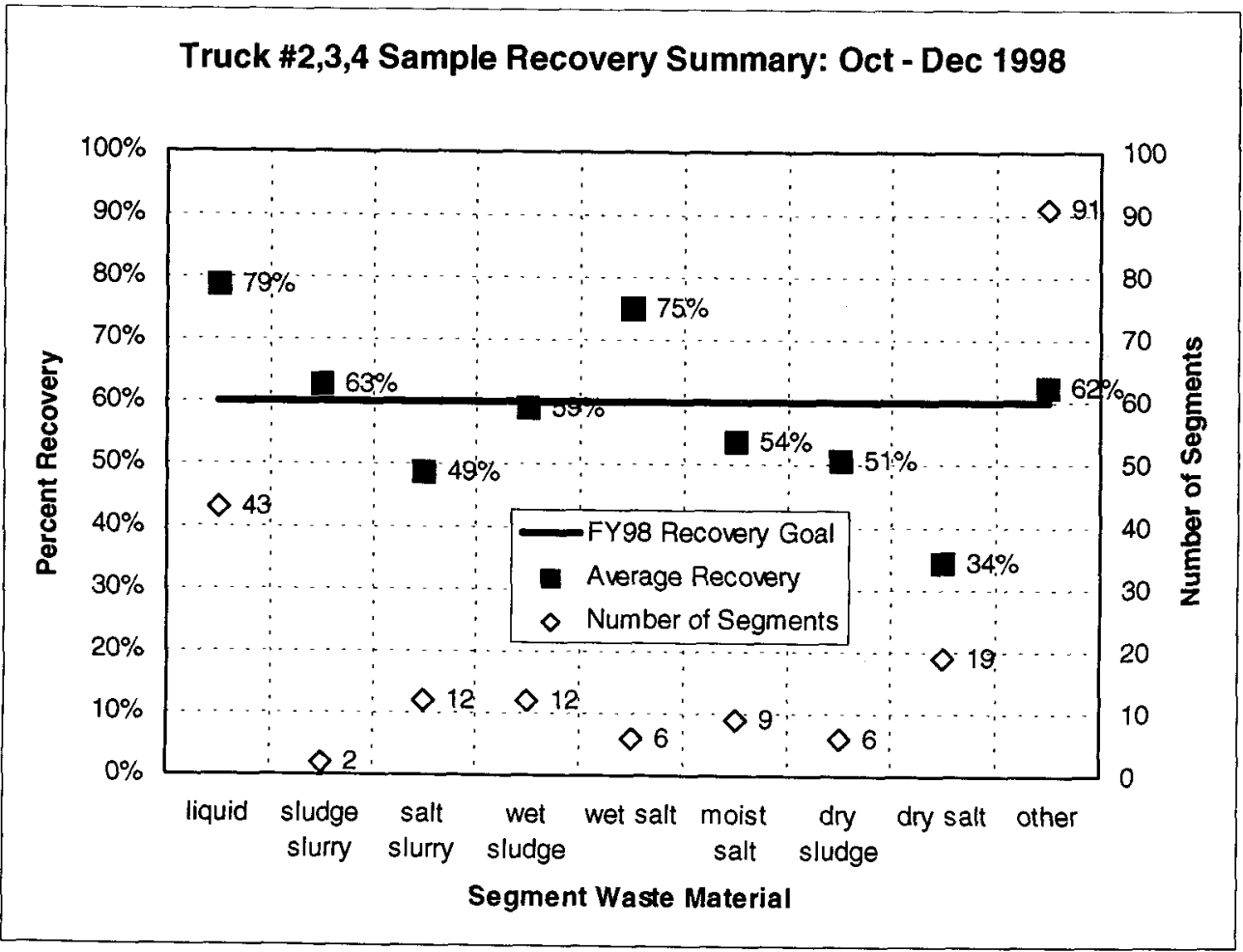


Figure 7: $\quad$ Truck \#1 Sampling System Availability

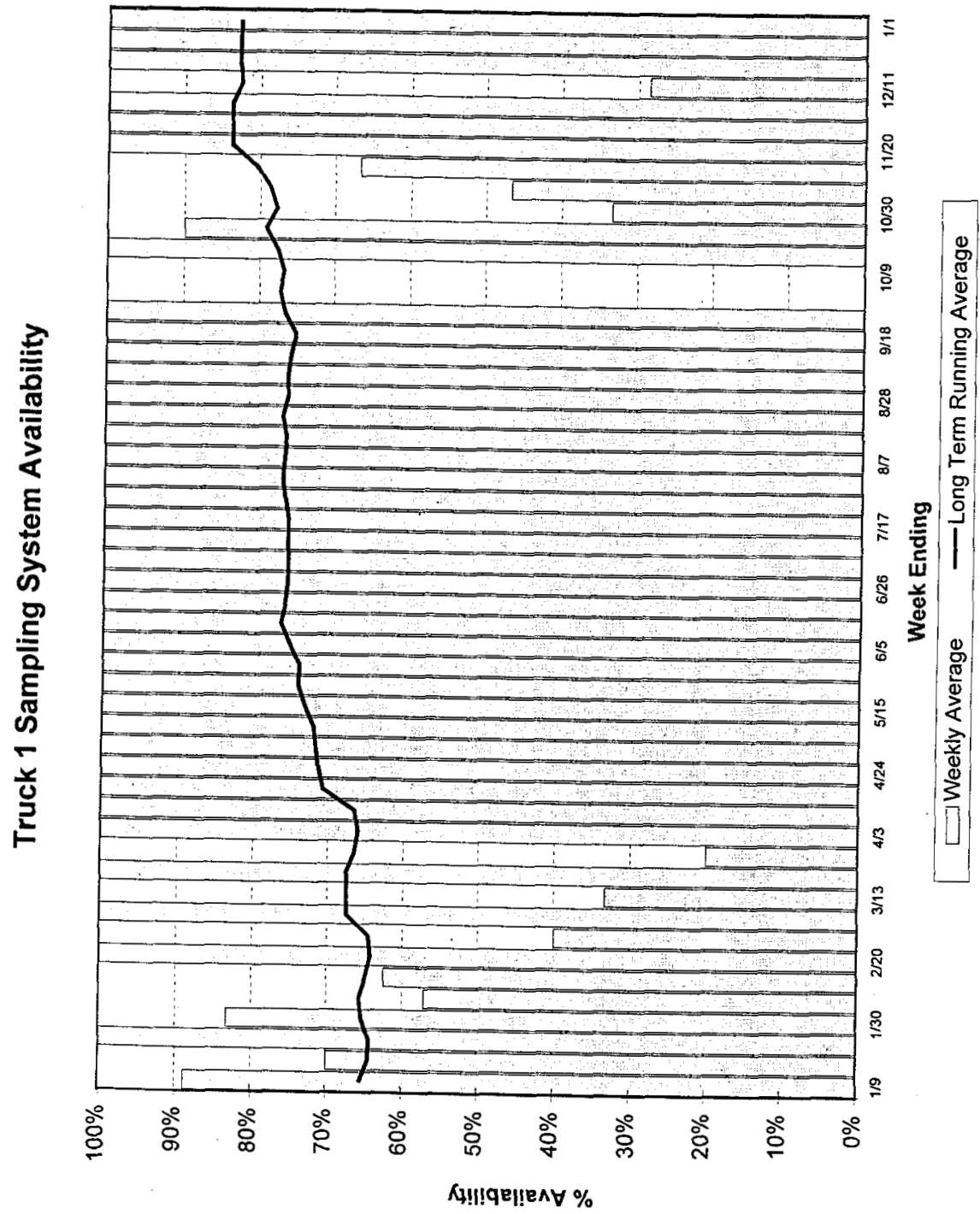

Page 30 of 33 
Figure 8: Truck \#3 Sampling System Availability

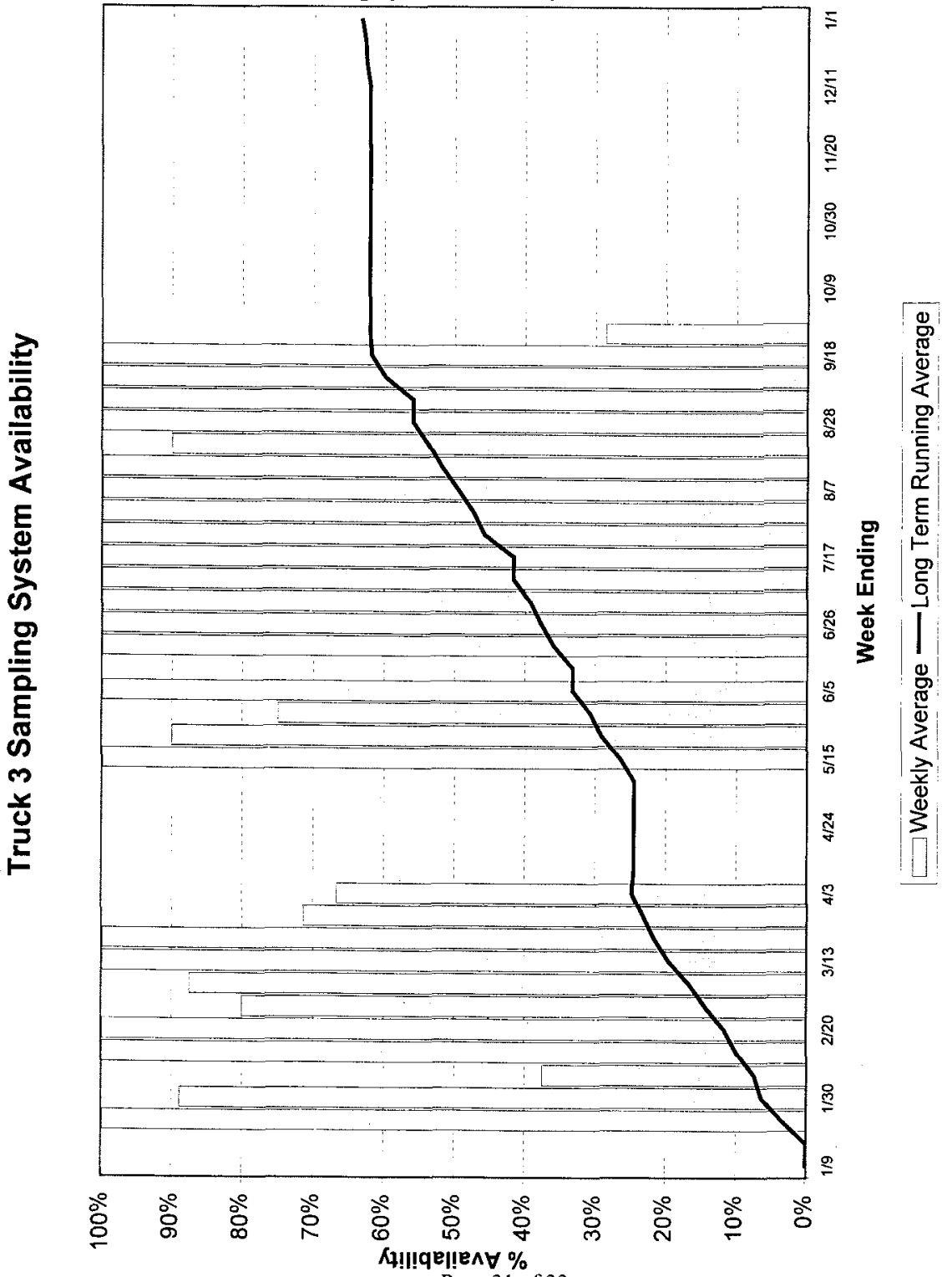

Page 31 of 33 
Figure 9: Truck \#4 Sampling System Availability

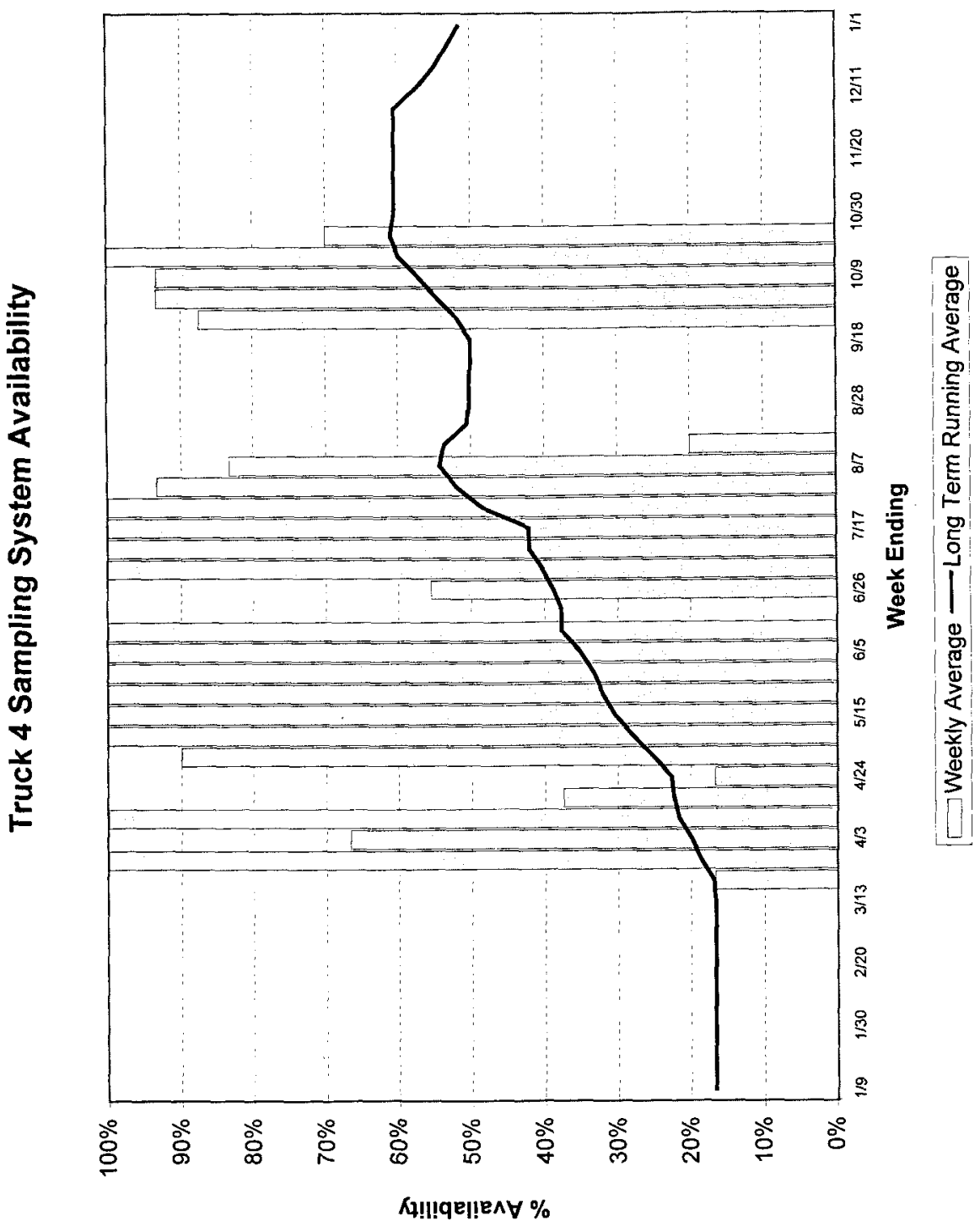

Page 32 of 33 
Figure 10: Characterization Equipment Engineering ECN Work Complete Status

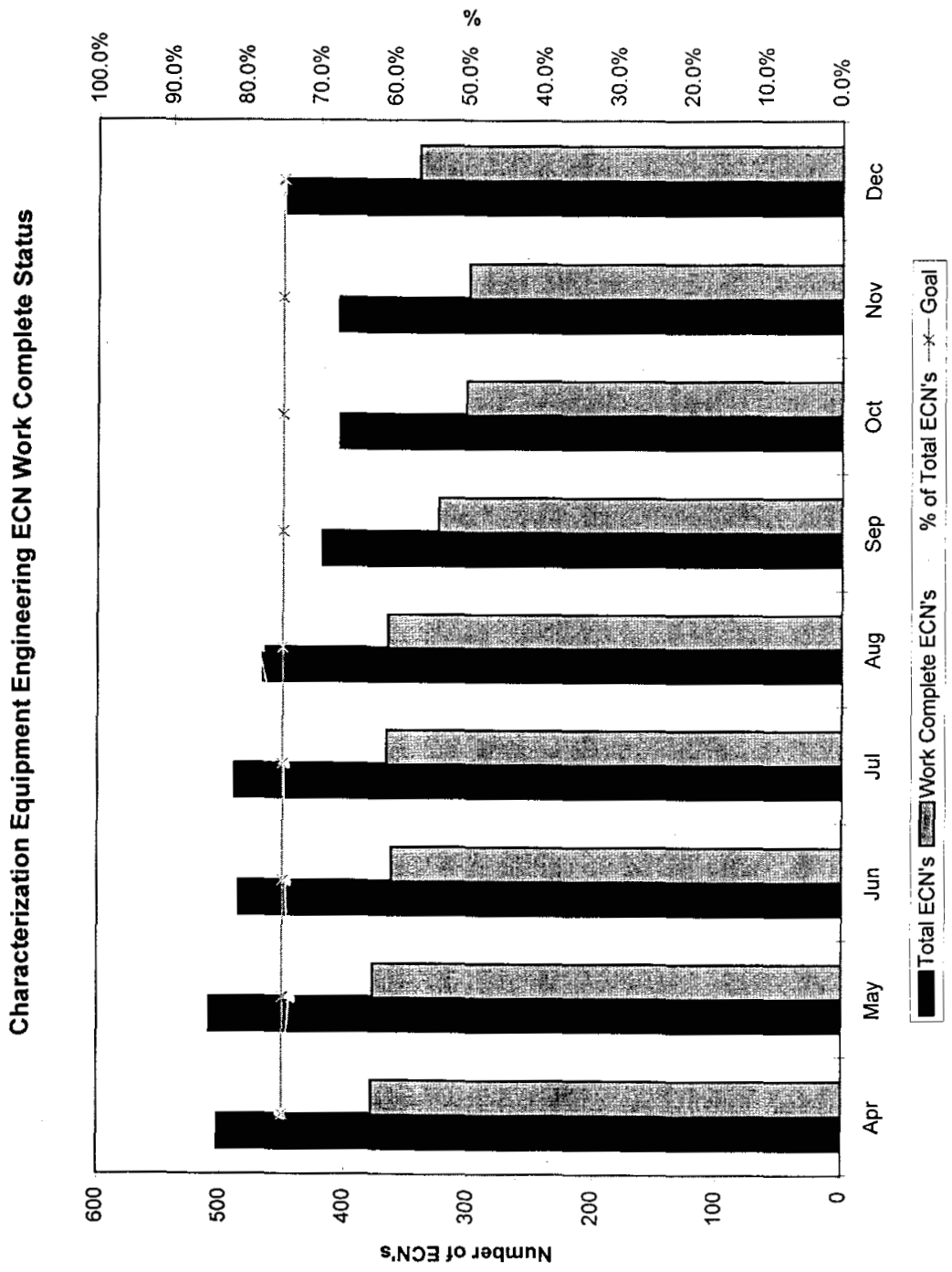

Page 33 of 33 